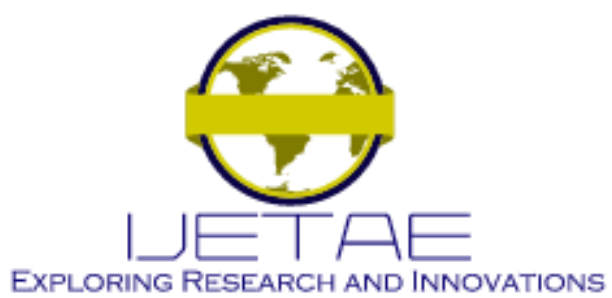

International Journal of Emerging Technology and Advanced Engineering

Website: www.ijetae.com (E-ISSN 2250-2459, Scopus Indexed, ISO 9001:2008 Certified Journal, Volume 11, Issue 10, October 2021)

\title{
Design of a Portable Electrocardiogram (ECG) for the Prevention of Cardiac Anomalies in Health Campaigns in Peru
}

\author{
Rosa Perez-Siguas ${ }^{1}$, Eduardo Matta-Solis ${ }^{2}$, Hernan Matta-Solis ${ }^{3}$ \\ ${ }^{1,2,3}$ Universidad María Auxiliadora \& Av. Canto Bello 431, San Juan de Lurigancho
}

\begin{abstract}
Cardiac complications are caused by an unbalanced diet, the consumption of alcohol, smoking tobacco, in addition to the excess of polluting gases such as carbon dioxide (CO2), among other gases that are harmful to the human body, due to these types of problems, they arise more frequently in people, which lead to heart problems at an early age. An optimal prevention of these cardiac abnormalities is necessary using an Electrocardiogram (ECG), by using this equipment it is possible to detect the cardiac anomalies that the person may have, thus giving early prevention for cardiac abnormalities that may be occurring in the patient. The design of a low-cost ECG will be considered using the AD8232 module, which allows recording the electrical activities of the heart, obtaining an ECG using the Arduino, in addition the Bluetooth module will send the data collected from the ECG from a patient to a cellphone which will store this information, to be later analyzed by a cardiologist. This paper is intended for use in health campaigns, given that according to the Pan American health organization, $70 \%$ of deaths in the world are due to heart problems, due to this figure, it is expected to reduce the rate with early prevention, which consists of the implementation of this biomedical equipment in health campaigns that will have the basic functionalities for the analysis of the electrocardiogram and that is low cost compared to biomedical equipment currently that provide the same functionalities.
\end{abstract}

Keywords- Electrocardiogram (ECG), cardiac abnormalities, biomedical equipment, Arduino, Health Campaigns

\section{INTRODUCTION}

According to the World Health Organization (WHO) indicates that heart disease is due to disorders of the heart and blood vessels, including: coronary heart disease (heart attack); cerebrovascular diseases (stroke); the increasing of the blood pressure (hypertension) [1]. An article published in the WHO indicated that 17 million deaths from cardiovascular diseases CVD, which represents $31 \%$ of all registered deaths in the world; from these deaths, 7.4 million were due to coronary heart disease, and 6.7 million were due to stroke [2].
The Pan American Health Organization (PAHO) indicated in one of its articles that non-communicable diseases, such as diabetes, cancer and heart disease, are responsible for more than $70 \%$ of all annual deaths in the world, this includes 15 million people who die prematurely, between the 30 and 69 years old, with more than $85 \%$ of these premature deaths occurring in the Netherlands and the middle country, being smoking, physical inactivity, and harmful consumption of alcohol, unhealthy diets and air pollution as the main causes [3]. For the decrease of these figures mentioned by the WHO and the PAHO, it is necessary to have a timely prevention encouraging good habits, so the authors will focus on prevention through the ECG, implementing biomedical electrocardiogram (ECG) devices in Health Campaigns.

The electrocardiogram (ECG) is the record of the electrical activity of the heart, the ECG signal is a weak low-frequency bipolar signal, and the normal signal intensity is $0.05-100 \mathrm{~Hz}$, its amplitude ranges from $10 \mu \mathrm{V}$ to $5 \mathrm{mV}$, the typical value is $1 \mathrm{mV}$, the ECG signal can help diagnose various diseases related to the heart [4]. As medicine and technology advance, new static or wireless biomedical devices are created, whose purpose is to have a better diagnosis in a short time, also in this way various diseases can be prevented. For this, portable biomedical devices are a key piece related to home care services, the ECG is the recorded electrical activities of the heart, allowing a doctor to discern heart symptoms and neuromuscular diseases [5]. ECG interpretation allows detection of many cardiac abnormalities including insufficient blood flow, death of the heart muscle due to coronary thrombosis, and enlargement of the heart muscle [6] It gives data about your heart rate and rhythm and indicates whether the heart is enlarged because of high blood pressure (hypertension) or a sign of a previous heart attack (myocardial infarction). 


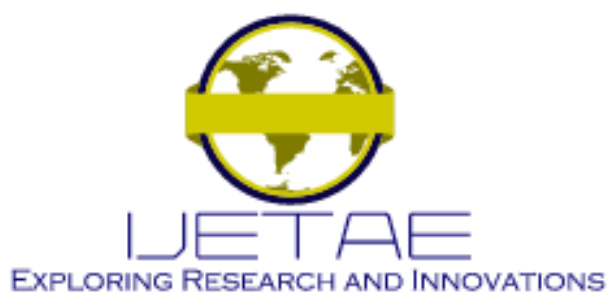

International Journal of Emerging Technology and Advanced Engineering

Website: www.ijetae.com (E-ISSN 2250-2459, Scopus Indexed, ISO 9001:2008 Certified Journal, Volume 11, Issue 10, October 2021)

According to Yair, he indicates that the mapping system of the patients' vital signs with heart difficulties can be improved, in order to encode these values and send them along with their geographical location through a wireless data network with fully supported LTE technology by the IP protocol with the physical infrastructure of hospital services and clinical history, in addition to generating an integration that allows a view of unified services [7].

A study at the Universidad Autónoma de Baja California indicated: Universities and institutes around the world have worked on these systems and although they differ in physical, technological or operational characteristics, they all meet the same objective: to record the ECG. Examples of these systems are those developed by companies such as The LifeSync ${ }^{\circledR}$ System, Nordic Semiconductor and Shimmer; also, they have included within their projects the design and implementation of device capable of obtaining the ECG wirelessly [8]. The signals that are collected by the three electrodes on the chest according to the standard positions of the Einthoven triangle, are taken to a circuit in charge of amplifying and filtering them, and then transferring to the Arduino UNO board. Then, Arduino sends by Bluetooth the signal to a mobile device carried by the user, so that it can send it to a workstation where the ECG is processed by an expert [8].

In the CSIE Department, Nan Hua University from Chiayi, Taiwan; it indicates that recently, monitoring of patient physiology and personal health care has been integrated into modern wireless e-health systems, bio signals provide a wealth of information in wireless data transmission [9].

In Peru, the implementation of portable biomedical device is not well-known, this makes it difficult to prevent cardiac abnormalities, given that its detection is late by late monitoring, which in most patients don't have a control in the health centers, one of the factors is the lifestyle that most of the population have. For this, health campaigns are carried out in different places of Peru, so that an early detection of CVD problems can be given, a wireless biomedical device is required, which is not generally available in these campaigns. For this, in this paper, it will be detailed in session II, the methodology will indicate the procedure to follow for an ECG, materials that are used in an ECG, it will briefly explain about the Einthoven triangle and signs of abnormalities in an ECG. Section III will present the design and parts of the biomedical device for ECG recording.
Session IV will show the results of the research work and a comparative table of a commercial device and an implemented one. Finally, Section V will present the discussion of the research word.

\section{METHODOLOGY}

The design of a portable ECG is proposed. First, it must have a knowledge of what is the procedure to follow for an ECG and the inputs that are needed to make an ECG. [10] To carry out the electrocardiogram, it is necessary to have the following supplies:

- Electrodes

- Graph paper

- Electrocardiograph

- Conductive material: soapy water, alcohol, and conductive paste.

- Bed sheet

- Gauze or paper tissue

- Pen

- Stretcher

- Disposable razor

The aforementioned lines are the basic supplies needed to implement an ECG on a patient, which leads to a procedure to be followed [11] which leads to the recognition of the patient to whom the ECG test is poured, which once the evaluation has finished, the patient is placed in a decubitus position where it is instructed to remove any accessory that is an electrical current conductor, so that the sample taken during the ECG is efficiently and correct, the patient is asked to relax, where previously the staff has with the supplies already ready and therefore maintaining adequate hygiene for the procedure, so that it can do a preliminary study of how the patient's skin is where the electrodes will be located, placing the conductive gel on the patient's skin to continue place the electrodes on the upper and lower extremities, once this is done, it proceed to place the cables of the unipolar derivatives as shown in Figure 1, therefore positioning the ECG paper at $25 \mathrm{~nm} / \mathrm{sec}$, with a register sensitivity of $1 \mathrm{mV}$ $=1 \mathrm{~cm}$ in height, $10 \mathrm{~mm} / \mathrm{mV}$ or an automatic adjustment, and once the ECG samples have been taken, the cables of the unipolar derivatives are removed together with the electrodes and the ECG must be attached to the clinical record to finish [11]. 


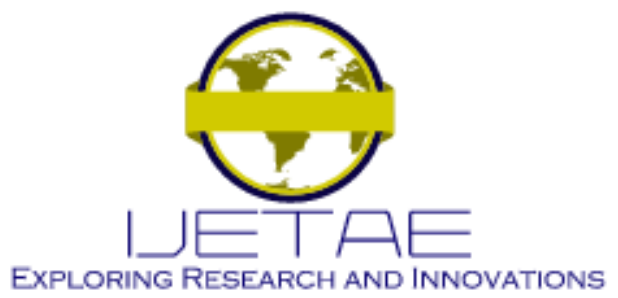

International Journal of Emerging Technology and Advanced Engineering

Website: www.ijetae.com (E-ISSN 2250-2459, Scopus Indexed, ISO 9001:2008 Certified Journal, Volume 11, Issue 10, October 2021)

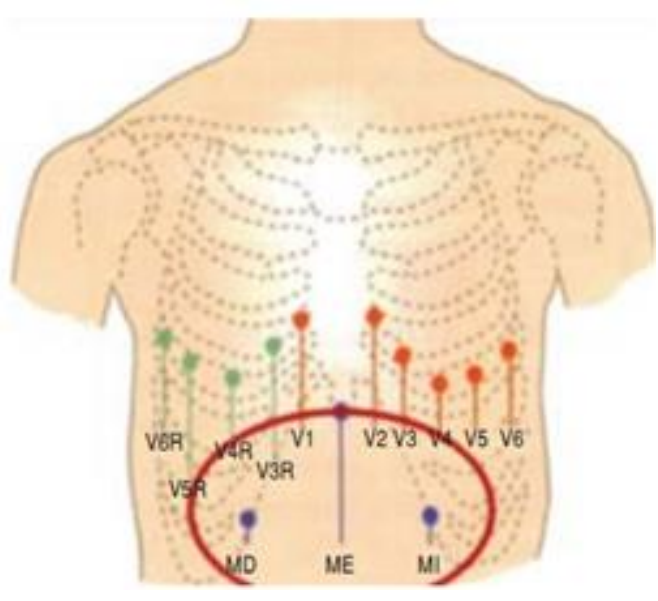

Fig 1 Medrano derivation

The design proposed in the paper will be portable, considering the theory of the Einthoven triangle. According to Toinga, it indicates that the objective of this device is to provide information about the electrical signals emitted by the heart and in this way, it can be determined if the organ is functioning normally [12]. Once knowing the theory of how one can consider the points necessary to have an ECG sample, a person could identify the normal signs that an older person must have [13].

Table 1

Range of Normal Signs in an Old Person

\begin{tabular}{|c|c|c|c|}
\hline & $\begin{array}{c}\text { NORMAL } \\
\text { AMPLITUDE } \\
\end{array}$ & $\begin{array}{l}\text { NORMAL } \\
\text { TIME }\end{array}$ & ALTERATIONS \\
\hline WAVE P & $<0.25 \mathrm{mV}$ & $<0.12 \mathrm{~s}$ & $\begin{array}{l}\text { Absent in atrial } \\
\text { fibrillation. } \\
\text { Atrial growths. }\end{array}$ \\
\hline $\begin{array}{l}\text { INTERVAL } \\
\text { PR }\end{array}$ & Isoelectric & $0.12-0.20 \mathrm{~s}$ & $\begin{array}{c}>0.20 \mathrm{~s} \\
\text { Atrioventricular block } \\
<0.12 \mathrm{~s} \text {. Preexcitation }\end{array}$ \\
\hline WAVE Q & $<25 \%$ of $\mathrm{R}$ & $<0.04 \mathrm{~s}$ & Old Infarction \\
\hline $\begin{array}{c}\text { QRS } \\
\text { COMPLEX }\end{array}$ & Variable & $<0.12 \mathrm{~s}$ & $\begin{array}{c}\text { Branch bundle block } \\
\text { of His }(\mathrm{HH})\end{array}$ \\
\hline $\begin{array}{l}\text { SEGMENT } \\
\text { ST }\end{array}$ & $\begin{array}{c}\text { Isoelectric } \\
\text { Men }<0.2 \mathrm{mV} \\
\text { in V2-V3 } \\
\text { Women }<0.15 \\
\mathrm{mV} \text { in } \mathrm{V} 2-\mathrm{V} 3\end{array}$ & $\begin{array}{c}\text { Not } \\
\text { applicable }\end{array}$ & $\begin{array}{c}\text { Early repolarization } \\
\text { (normal). } \\
\text { Acute myocardial } \\
\text { infarction. } \\
\text { Left bundle branch } \\
\text { block. } \\
\text { Pericarditis. }\end{array}$ \\
\hline $\begin{array}{l}\text { INTERVAL } \\
\text { QT }\end{array}$ & Not applicable & $<0.45 \mathrm{~s}$ & $\begin{array}{c}\text { QT Long due to } \\
\text { hypocalcemia, drugs } \\
\text { (p, e), antipsychotics, } \\
\text { macrolides, } \\
\text { quinolones, azoles }\end{array}$ \\
\hline WAVE T & Less than QRS & $\begin{array}{c}\text { Not } \\
\text { applicable }\end{array}$ & $\begin{array}{c}\text { Amplitude increases in } \\
\text { hyperkalemia }\end{array}$ \\
\hline
\end{tabular}

\section{A. Einthoven's Triangle}

The proposed biomedical device will be portable, it will base on the einthoven triangle theory, as shown in Figure 2, based on these points, the electrodes will be placed on the patient for take the ECG sampling.

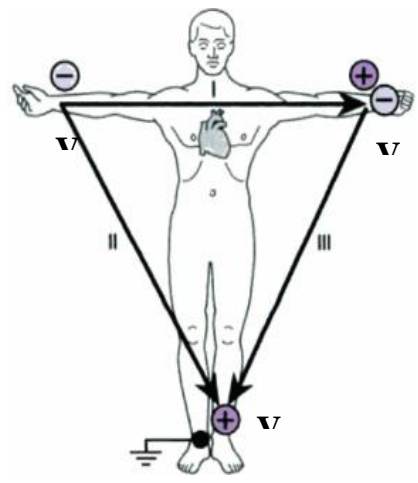

Fig 2 Einthoven's triangle

The advancement of technology is growing in the Biomedical part, there are already electronic boards which are made up of different electronic components based on do some operation, which with the help of programming, in this case using a language programming in $\mathrm{C}++$, these electronic boards can be programmed based on the needs and requirements. For this design, it will consider the Arduino Pro mini programmable card, with the AD8232 module, it allows to record the electrical activity of the heart to obtain an ECG signal. The AD8232 is an integrated circuit with signal amplifiers and noise filters specially calibrated for ECG signals. The module suppresses $60 \mathrm{~Hz}$ noise generated by household electricity. The output of the module is analog type, it is necessary to solder the pins and connect the module to a microcontroller such as Arduino. In the programing, it must change the analog to digital conversion and thus it can observe the ECG on the Arduino serial plotter.

Table 2

AD232 CONNECTION TABLE

\begin{tabular}{|c|c|c|}
\hline Board Label & Pin Function & $\begin{array}{c}\text { Arduino } \\
\text { Connection }\end{array}$ \\
\hline GND & Ground & GND \\
\hline $3.3 \mathrm{~V}$ & $3.3 \mathrm{v}$ power supply & $3.3 \mathrm{~V}$ \\
\hline Output & output signal & A0 \\
\hline L0- & Lead detection - & 11 \\
\hline L0+ & Lead detection + & 10 \\
\hline SDN & Shutdown & Not used \\
\hline
\end{tabular}




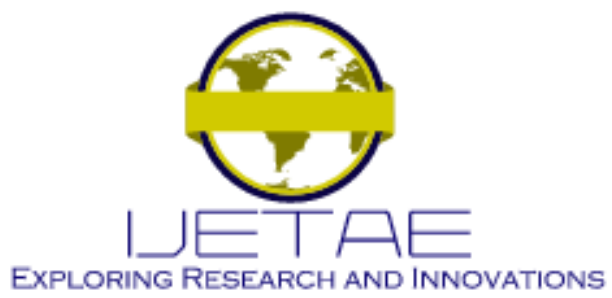

International Journal of Emerging Technology and Advanced Engineering Website: www.ijetae.com (E-ISSN 2250-2459, Scopus Indexed, ISO 9001:2008 Certified Journal, Volume 11, Issue 10, October 2021)

Table II indicates connections that were made to operate the AD8232 module. In Figure 3, it is the diagram that was used to make the AD8232 module work, which should take into account that the connection method used is based on pins, Pulse Width Modulation (PWM), however, if the connection is done to other pin, the displayed signal will be null.

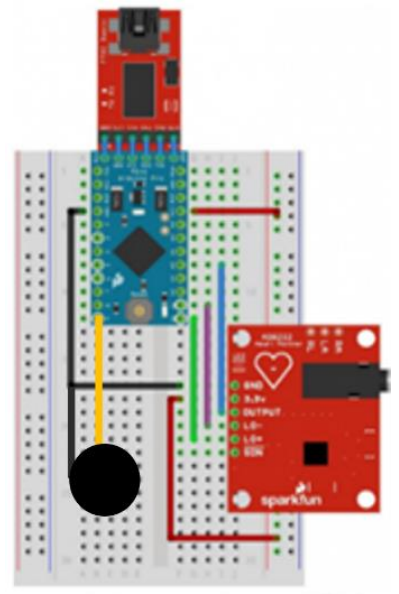

Fig 3 Basic operating diagram for the AD8232 module

To operate the system, an algorithm has been developed, of which it can see its flow diagram in Figure 4, it can see the processes that the Arduino performs to analysis an ECG; the process begins, with the declaration of the variables necessary for the whole process, followed by the configuration of the digital pins previously named in table II as inputs or outputs (I/O), in addition to the configuration of serial communication and the connection via Bluetooth; the main loop can be seen in the Loop section, which is repeated indefinitely, this loop begins with the verification of the data collection start order, sent from the app on the cell phone, then when the order is confirmed it proceeds to take the ECG data, then the heart rate is calculated and according to this the characteristic sound of cardiac monitoring equipment is emitted, which is a beep for each heartbeat, otherwise a continuous sound is emitted; then the ECG and heart rate data are sent via Bluetooth to the developed app.

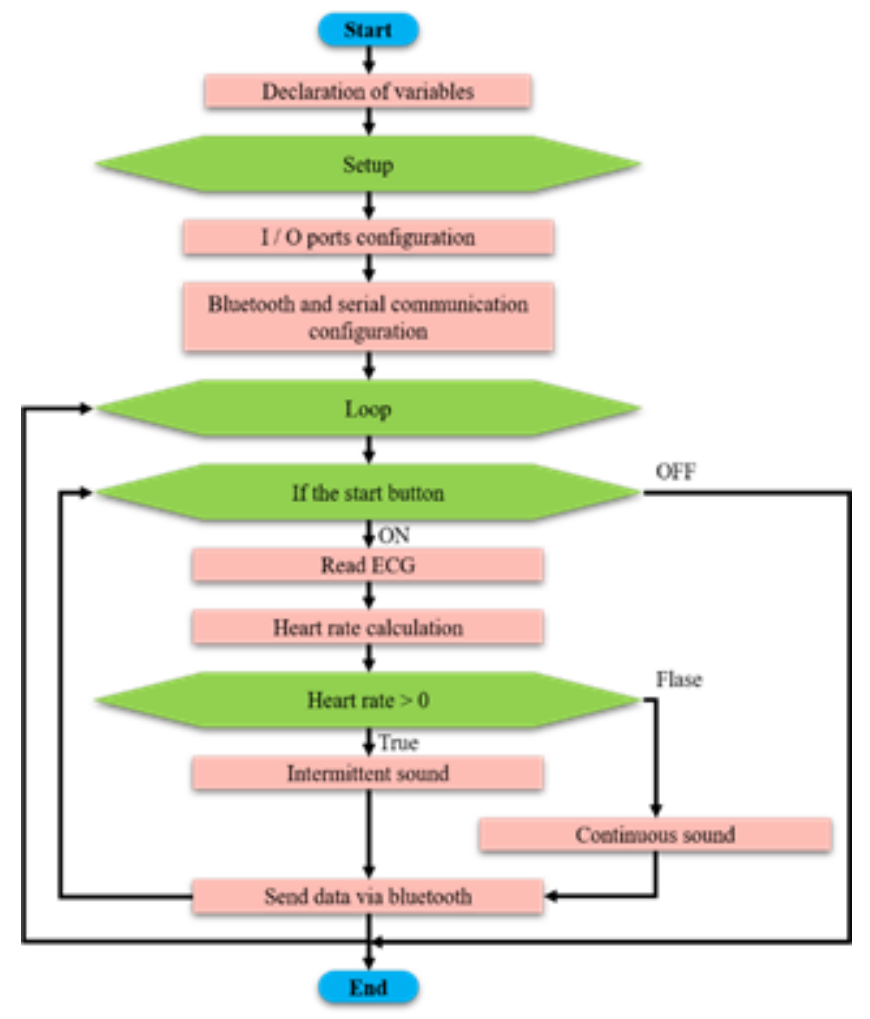

Fig 4 Flow Chart

The app has been developed for Android mobile devices, as can be seen in Figure 4, this application has the respective buttons for connecting and disconnecting via Bluetooth to the developed device, as well as having the buttons: Start, which is in charge of starting the data transmission, which we can see in real time at the bottom of the mobile device, both the ECG signal and the patient's beats per minute, finally we have the Stop button, which is responsible for ending the data transmission and Therefore the evaluation of the ECG, it is worth mentioning that the data obtained is stored in an internal database of the cell phone, which is synchronized with a general database when the mobile device has internet access, in this way a specialized doctor could evaluate results remotely. 


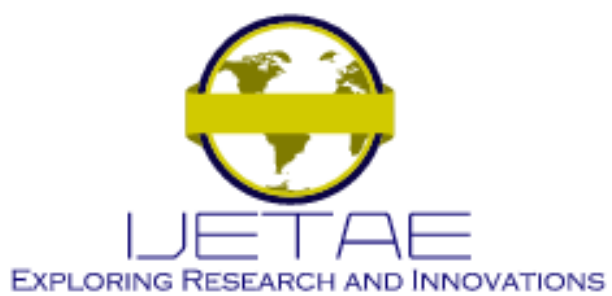

International Journal of Emerging Technology and Advanced Engineering Website: www.ijetae.com (E-ISSN 2250-2459, Scopus Indexed, ISO 9001:2008 Certified Journal, Volume 11, Issue 10, October 2021)

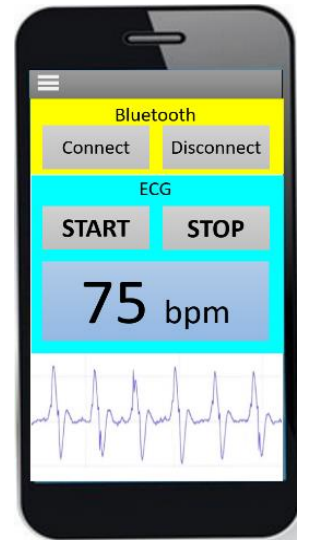

Fig 5 App developed in Android studio

\section{RESULTS}

It was possible to obtain a reliable reading with an ECG, in which the design of the biomedical device can be improved, which will be complemented with the AD8232 module, a digital screen where the ECG readings can be displayed. Therefore, the Arduino serial plotter was used to observe the ECG sample as shown in Figure 5. Already having the sample, it can be stored on a mobile device, also it will be filed in the cloud so it can be analyzed by a specialist. Having this portable ECG biomedical device, it must be certified so it can be equipped in health campaigns due to its low production cost. Moreover, prevention diagnoses can be obtained, which can take a second sample of an ECG in the same hospital center that may have referred the treated patient to verify the anomaly the patient could have.

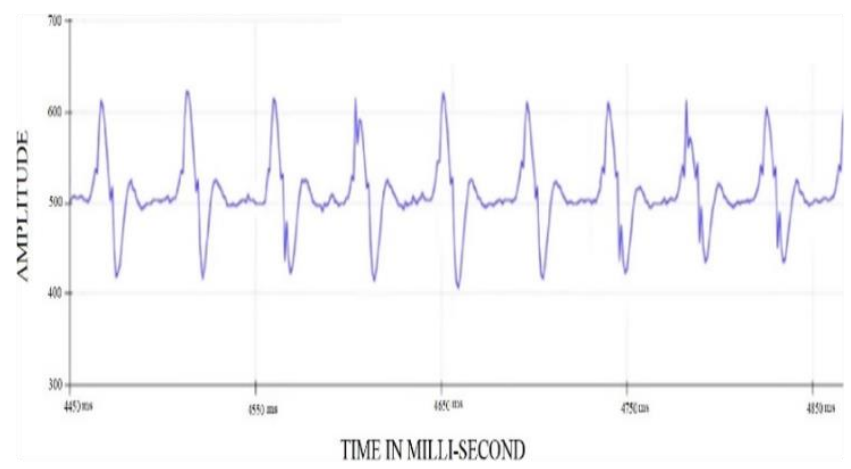

Fig 6 Simple sample of an ECG

To have reliable results of samples, following the ethical standards, a study was carried out at the Universidad María Auxiliadora in 763 students, to have a sample and compare it with the biomedical device.
This compare shows an effectiveness of $95 \%$, the biomedical device designed could be useful for low cost campaign.

The study carried out in 763 participants, 157 students presented cardiac difficulties during the sampling process, being $20.57 \%$ of the students involved, all thanks to our device and the app developed, it was possible to remotely evaluate the results by a specialist, with this is demonstrated the functionality of our development.

\section{DISCUSSION}

The paper has been based on the approach of a biomedical device that can sample cardiac activities as a portable ECG, it is desired that it performs in precautionary campaigns for older adults, giving a first diagnosis. Therefore, there are already portable ECG biomedical equipment on the market, ranging from $\$ 500.00$ to $\$$ 2000.00 , the most basic and most advanced, it costs \$ $23,000.00$ which its function is similar to the paper also the design in the paper will cost much less than $\$ 500.00$, as we can see in Table III.

In [4] a device is developed in addition to a mobile application only to observe the signals obtained, however they do not have the remote evaluation that we have; in [5] a circuit capable of carrying out ECG and EMG readings is developed but they do not have an application or the possibility of an evaluation or remote by specialists; in [8] they developed an ECG acquisition system, through a mobile application to observe the results and finally a connection via Wi-Fi to a PC where the results can also be observed, compared to this work, our development does not have the connection to a pc, but if it has synchronization with a data server, from which the results obtained in the tests carried out can be observed.

Table 3

Comparative Table Between A Commercial ECG And Implemented Based On Arduino

\begin{tabular}{|c|c|c|}
\hline & $\begin{array}{c}\text { BASIC PORTABLE } \\
\text { COMMIERCIAL } \\
\text { ECG }\end{array}$ & $\begin{array}{c}\text { ECG WITH } \\
\text { ARDUINO }\end{array}$ \\
\hline Price & S/. 1.600 .00 & S/. 500.00 \\
\hline Quick Measurement & 30 saconds & 50 seconds \\
\hline $\begin{array}{c}\text { Measurement } \\
\text { Electrodes }\end{array}$ & 3 & 3 \\
\hline $\begin{array}{c}\text { Heart Rate Range } \\
\text { Data Management }\end{array}$ & $30 \mathrm{bpm}-240 \mathrm{bpm}$ & Adsaptable \\
\hline Loading data & BLUETOOTH & $\begin{array}{c}\text { BLUETOOTH, } \\
\text { CLOUD }\end{array}$ \\
\hline
\end{tabular}




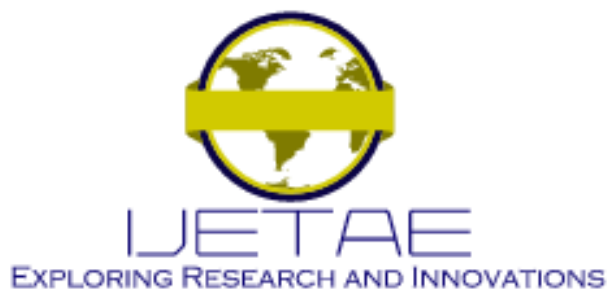

International Journal of Emerging Technology and Advanced Engineering

Website: www.ijetae.com (E-ISSN 2250-2459, Scopus Indexed, ISO 9001:2008 Certified Journal, Volume 11, Issue 10, October 2021)

\section{CONCLUSIONS}

As we have already observed throughout this research work, it has been possible to build a stable structure for remote ECG evaluation, through the use of agile platforms such as the Arduino; Finally, an application was built, capable of controlling the acquisition of data, as well as showing the information obtained remotely to a specialist for the correct evaluation of the results.

As future work, the possibility of incorporating signal processing with artificial intelligence is considered to detect cardiac anomalies early and thus be able to inform the specialist of a possible cardiac condition in advance, so that it can quickly verify and decide the treatment to follow.

\section{REFERENCES}

[1] W. H. O. (WHO). (2019) Enfermedades cardiovasculares. [Online]. Available: https://www.who.int/topics/cardiovascular diseases/es/

[2] W. H. Organization. (2017) Enfermedad pulmonar ibstructiva crónica. [Online]. Available: https://www.who.int/es/newsroom/factsheets/detail/cardiovascular-diseases-(cvds)

[3] O. P. de la salud (OPS). (2019) Cuáles son las 10 principales amenazas a la salud en 2019. Available: https://www.paho.org/

[4] M. A. Ahamed, M. Hasan, and M. Alam, "Design and implementation of low cost ecg monitoring system for the patient using smartphone," 112015 , pp. 261-264.

[5] L. Shin-Chi, H. Ying-Hsiu, and C. Ying-Ting, "Low-cost prototype design of biomedical sensing device for ecg and emg signal acquisition system," 06 2018, pp. 1-2.
[6] M. A. Ahamed, M. Asraf-Ul-Ahad, M. H. A. Sohag, and M. Ahmad, "Development of low cost wireless ecg data acquisition system," in 2015 International Conference on Advances in Electrical Engineering (ICAEE), 2015, pp. 72-75.

[7] Y. Rivera, "Design of a ubiquitous architecture arduino-based telemedicine for monitoring signals through biometric technology 1te," in 2016 8th Euro American Conference on Telematics and Information Systems (EATIS), 2016, pp. 1-5.

[8] Y. Ungson, M. A. Reyna, and M. E. Bravo-Zanoguera, "Development of an ambulatory ecg system based on arduino and mobile telephony for wireless transmission," in 2014 Pan American Health Care Exchanges (PAHCE), 2014, pp. 1-5.

[9] S. C. Lai, W. C. Li, S. H. You, D. W. Jhuang, and S. T. Gao, "Lowcost and low-complexity electrocardiogram signal recorder design based on arduino platform," in 2014 Tenth International Conference on Intelligent Information Hiding and Multimedia Signal Processing, 2014, pp. 309-312.

[10] B. D. Carolina, Técnicas en A.P. Realización de Electrocardiograma, 1st ed., 2005.

[11] L. Silvia, H. Maria, and G. Imelda, Intervenciones de enfermería en la toma de toma de electrocardiograma, circulo torácico y medrano, 7th ed., 2014.

[12] S. E. Toinga Villafuerte. (2017) Diseño e implementación de un módulo didáctico para la enseñanza interactiva del concepto del triángulo de Einthoven. Available: https://bibdigital.epn.edu.ec/handle/15000/18874

[13] J. I. L. Prado. (2016) El electrocardiograma: una oportunidad de aprendizaje. http://www.scielo.org.mx/scielo.php?script ${ }^{-}$sci arttext\&pid ${ }^{-}$S002617422016000600 